\title{
Pakistan's Quest for a New Growth Vent: Lessons from History
}

\section{Ijaz Nabi*}

\begin{abstract}
This article argues that a new growth vent in Pakistan requires tapping into external lucrative markets in a manner that will create multiple entre-ports for growth. Such a growth vent will enable the country to achieve a sustained growth path that is not as susceptible to the political vicissitudes of one mega-growth node. This will be good for regional equity within the country and will also bring new energy to the Indus Basin market. Sustained welfare improvements in this type of regional hub can occur when it transitions from being a transportation hub for goods and energy into a manufacturing hub that creates high-productivity, highwage jobs in multiple regional growth nodes.
\end{abstract}

Keywords: Regional hub, trade, GDP, Pakistan.

JEL classification: F43.

\section{Introduction}

Economic growth of 7 percent or more in the coming decades will double Pakistan's GDP every ten years and in four decades will result in a substantial improvement in per capita income. This is not such a tall order, being just 1 percentage point higher than the growth rate that the country has achieved over several decades in the past, and only 2 percentage points higher than the average growth rate since 1947. There is, however, an important caveat. Pakistan has to seek a source of growth, or a "growth vent," that results in geographically balanced growth and can thus be sustained politically for a prolonged period of time. This requires tapping into lucrative markets outside the borders in the neighborhood in a manner that creates several growth nodes, i.e., Karachi, the Arabian Sea coastline of Sindh and Balochistan, Lahore, and Peshawar.

This article reviews Pakistan's recent growth vents and their impact on the economy in terms of creating a vibrant Indus basin market. It then

\footnotetext{
* Visiting Professor, Lahore University of Management Sciences and Country Director of the International Growth Centre, Pakistan.
} 
argues that the new growth vent that Pakistan seeks requires recreating historical trade routes. This will be good for regional equity within the country and will also bring new energy to the Indus Basin market.

\section{Pakistan's Principal Growth Vents}

The region that constitutes Pakistan has seen at least five major vents for economic growth in the last 100 years, as described below.

\subsection{Canal Irrigation}

Starting in the 1860s, the Indian subcontinent saw a remarkable expansion of the irrigation system. For 60 years, the average annual increase in the area under canal irrigation was a phenomenal 50,000 acres (Stone, 1984, p. 340). Punjab, Sindh, and parts of Khyber Pakhtunkhwa benefited substantially from this phase of canal expansion in British India.

Canals were preferred over previous modes of irrigation, not only because of the lower unit costs but also because they extended the range of cropping options for farmers, who could then water crops at their own discretion. These benefits resulted in both intensive and extensive land cultivation, thereby increasing production and, hence, the rate of return to agriculture. Several complementary developments-a legal framework governing land-related transactions, a network of roads and railways, and public services such as education, health, and policing-kick-started economic growth in the regions constituting the Indus Basin market and brought about a substantial increase in income and living standards for nearly 100 years.

\subsection{The Korean War and Import-Substituting Industrialization}

The second major growth vent is associated with the Korean War. Pakistan's economic managers made a strategic decision in 1949 not to devalue the rupee with respect to the US dollar when Britain devalued the pound and India (the rupee was linked to the British pound) followed suit. Pakistan's rationale was that capital goods had to be imported in order to industrialize and that, therefore, the rupee had to be strong.

The world events that followed supported Pakistan's decision. The Korean War, which broke out soon after the Second World War, led to stockpiling because of the fear of shortages of critical raw material. The jute and cotton produced by Pakistan benefited from the resulting price increase (in four months, the price of $289 \mathrm{~F}$ Punjab cotton rose by 80.3 
percent from PKR 81/maund to PKR 146/maund). This strengthened the rupee and resulted in the accumulation of reserves. India, a major importer of Pakistani cotton and jute, had countered Pakistan's decision not to devalue the rupee by banning imports from Pakistan. This gave Pakistan the opportunity to diversify exports to nontraditional markets and look to foreign trade as a source of sustained economic growth. The fiscal account also became favorable as government revenue increased on account of the export duties imposed, contributing an additional 2 percent of gross national product (GNP) (Hasan, 1998, p. 113).

By not devaluing the rupee, the government kept the cost of imported capital goods low. This was accompanied by import controls, especially on consumer goods, that slanted the incentive regime in favor of industrial production (Zaidi, 2005, p. 93) and launched a period of importsubstituting industrialization in the 1950s. The policy that Pakistan followed has been summarized as "produc(ing) anything that can be reasonably produced domestically... once production has started domestically, ban imports of competing goods so as to save foreign exchange" (Lewis, 1969, p. 70).

Import-substituting industrialization proved to be very successful, particularly in the heavily protected consumption goods industries. Textiles also expanded spectacularly. However, heavy protection exacted a price - the lack of competition resulted in less efficient production (Hasan, 1998, p. 116). The strategy also led to a high concentration of wealth, both regional and interpersonal. At the time, 22 families allegedly controlled 80 percent of the country's assets. Manufacturing was concentrated primarily in Lahore, Karachi, and Faisalabad, which together accounted for 60 percent of the total value-added in 1959/60. This disparity persisted for a decade and contributed to the dissatisfaction that eventually resulted in East Pakistan separating from the federation.

\subsection{The Green Revolution}

Ayub Khan's government began to focus on agriculture in the 1960s, which had stagnated as policy, energy, and incentives (especially via the exchange rate) were directed to implementing import-substituting industrialization. During the first half of the 1960s, there was massive investment in irrigation: Link canals were dug, the Mangla dam was constructed, and the number of tube-wells increased from a few hundred in 1960 to 75,000 by 1968 and a whopping 156,000 by 1975 (Zaidi, 2005, p. 30). The well-timed availability of water was necessary to introduce a 
technology package of high-yield varieties of seed, fertilizers, and pesticides, initially focusing on two crops: Mexi-Pak (adapting research from Mexico to Pakistan) and IRRI rice (research based in the Philippines). Between 1960 and 1970, the Mexi-Pak and IRRI output increased by 91 and 141 percent, respectively (Zaidi, 2005, p. 29). Between 1965 and 1970, the average wheat yield rose by around 50 percent per ha (Hamid \& Tims, 1990, p. 14). The agricultural growth rate started rising in the early 1960s within the range of 3-6 percent, but after 1966, when all the agricultural inputs had been improved, growth rates jumped to 10 percent per annum.

\subsection{Overseas Migration and Remittances}

The 1970s and 1980s were characterized by a large outflow of labor, both skilled and unskilled, from Pakistan to the Middle East. This was facilitated by a liberal labor export policy. The number of migrant workers increased from 79,000 per annum in the 1970s to 107,000 in the 1980 s, and remittances jumped from USD 565 million to USD 2.3 billion per annum, respectively. The high volume of remittance income was geographically spread, benefitting even less well-off regions. At the household level, remittances improved the living standards of recipient families, propelling them to middle-class status. The foreign exchange that workers sent home also had macroeconomic benefits, allowing a high volume of imports at a relatively stable exchange rate.

However, there was a downside. Remittances fuelled consumptionled growth for nearly three decades, contributing to the loss of international competitiveness in manufacturing. This was both because of the high equilibrium exchange rate as well as the broader consumptionfavoring policy environment (energy pricing, credit allocation, tax regime, public investment in transport, etc.; see Nabi, 2010). This manifestation of the "Dutch disease" in Pakistan contributed to the anemic growth of manufacturing and the paucity of high-productivity, high-wage jobs.

\subsection{The "War Against Terror"}

A major growth spurt occurred under Musharraf in 2002-07. For its role in the war against terror, Pakistan was rewarded in terms of concessionary capital from international financial institutions. A substantial portion of the country's external debt was written off and rescheduled, and foreign direct investment (FDI) increased. Remittances, which had fallen sharply in the preceding years, shot up again as confidence in the rupee was restored. This resulted in a substantial improvement in Pakistan's balance of payment, which recorded a surplus 
of USD 2.7 billion in the early 2000s (Mullick, 2004). GDP growth, which had been at 3.1 percent in 2001/02, began to rise, reaching 6.8 percent by 2006/07. From a deficit of 0.3 percent of GDP in 2000, the current account balance improved to a surplus of 4.9 percent of GDP by 2003.

However, the end years of this growth phase (2006-08) coincided with rising inflation and energy shortfalls. The share of investment and manufacturing in GDP and employment did not show any increase, growth in imports far exceeded that of exports, and the tax-to-GDP ratio stagnated. Growth and its salutary effects were, therefore, short lived.

\subsection{Assessing Pakistan's Growth Cycles}

Figure 1 shows an oscillating growth pattern-the boom-and-bust cycles of Pakistan's growth. There appear to be ten-year cycles. The 1960s and 1980s (with growth in most years above 6 percent) were decades of robust growth, while the 1970s and 1990s (with an average growth rate of around 4 percent) saw modest growth. The 2000s experienced high growth in 2001-07, followed by a slump starting in 2008.

\section{Figure 1. Annual GDP growth (\%)}

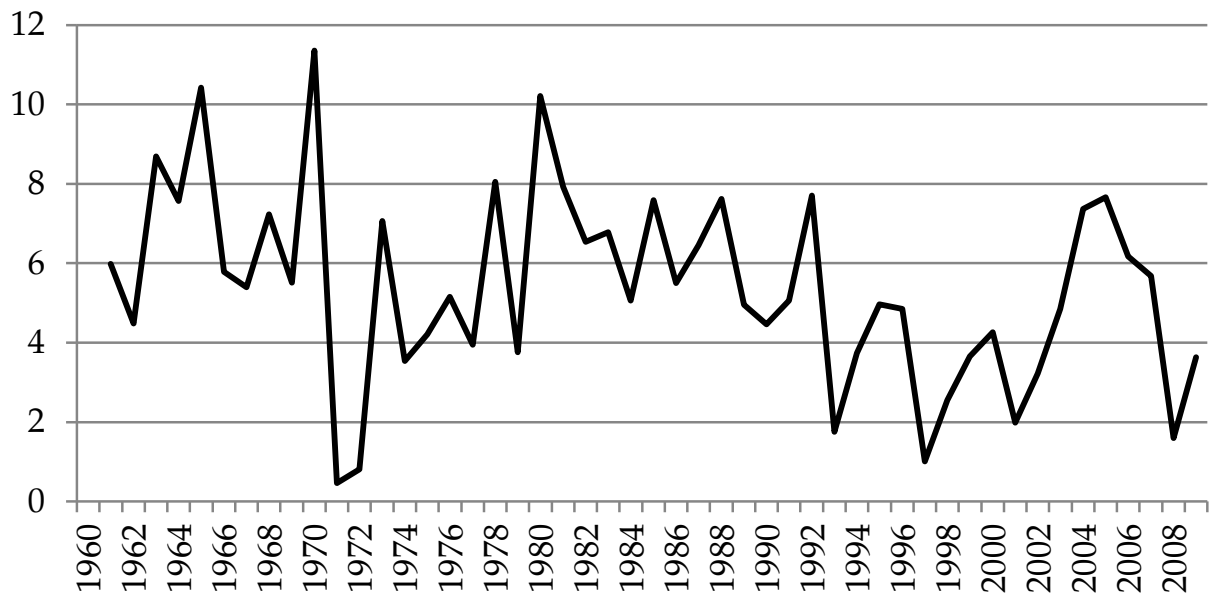

Source: World Bank (2010), World development indicators.

Assessing these growth vents in term of their effect on regionally balanced growth, the canal colonies would rank first, followed by the Green Revolution. Protection and industrialization would be a distant third, both because they could not be sustained and because they resulted in unbalanced growth. Migration to the Gulf is fourth, simply because the 
primary stimulus comes from outside and we have not yet found a way of climbing up the skills ladder; the growth vent is thus vulnerable. The externally financed, geopolitically driven, growth spurts under Zia and Musharraf fail the sustainability criteria; the latter was, geographically, decidedly unbalanced, and also increased inequality across income groups.

Another way to look at the growth of the last six decades is in terms of the creation, perhaps for the first time in history, of an integrated Indus Basin market. A strong and interdependent market for products, labor, and financial flows has been created between the Indian border to the east and the Indus River to the west (Figure 2). Pakistan's economic managers wisely invested in a communications infrastructure spanning railways, ports, roads, a postal system, and telephones, which has been key to the development of the Indus Basin market. Spokes in the southwest extend the market to Quetta in Balochistan and in the northeast to the regions of the Karakorams and the Hindu Kush. The market enjoys perhaps the best connectivity of any subregion in South Asia. The National Trade Corridor (NTC) links Peshawar, through Lahore to Karachi and Port Qasim, and "handles the major part of Pakistan's external and internal trade" (World Bank, 2006, p. 8). The World Bank also points out that

the bulk of Pakistan's international trade, about 40 million tons per annum... is transported by road along this main corridor. Almost all of this trade ( 95 percent) is handled by the two seaports of Karachi and Port Qasim, located about $50 \mathrm{~km}$ from each other. Pakistan's trade is characterized by a concentration of movements within the country (mainly along the NTC), a small number of export destinations and import origins (2006, p. 17).

This connectivity has, therefore, facilitated Pakistan's growth spurts and the sharing of welfare from that growth across a wide region. 


\section{Figure 2: Pakistan's Indus Basin market along the north-south trade corridor}

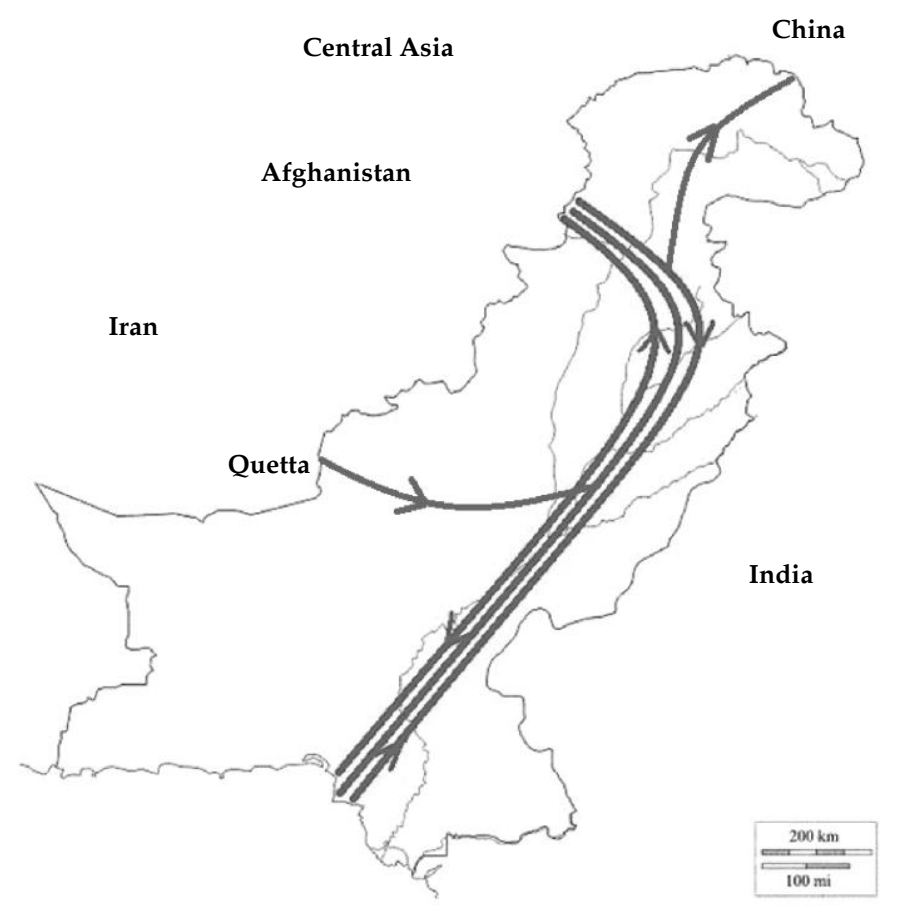

\section{Recent Growth Performance}

The search for a new growth vent, one that builds on the strengths of the NTC and the Indus Basin market to give Pakistan sustained, high, and regionally balanced economic growth, has to begin with an assessment of the country's recent lackluster growth performance. To that end, a comparison with India's economic performance is useful. India's recent GDP growth rate (averaging 8 percent) is more than twice that of Pakistan (Figure 3). Moreover, because India's population growth is lower, its per capita income is growing even faster (Figure 4).

This divergent economic performance has two implications. First, in the not-too-distant future, living standards, including the quality of infrastructure and public services, will be better in India. (See also Table 1.) Significantly, the country will also have a larger lobbying presence at international forums, which will have consequences for Pakistan's ability to maintain parity across a broad range of contested and competing issues. Second, India's capacity to modernize its security establishment will be far greater than Pakistan's. 
Figure 3: GDP growth in India and Pakistan 1980-2008

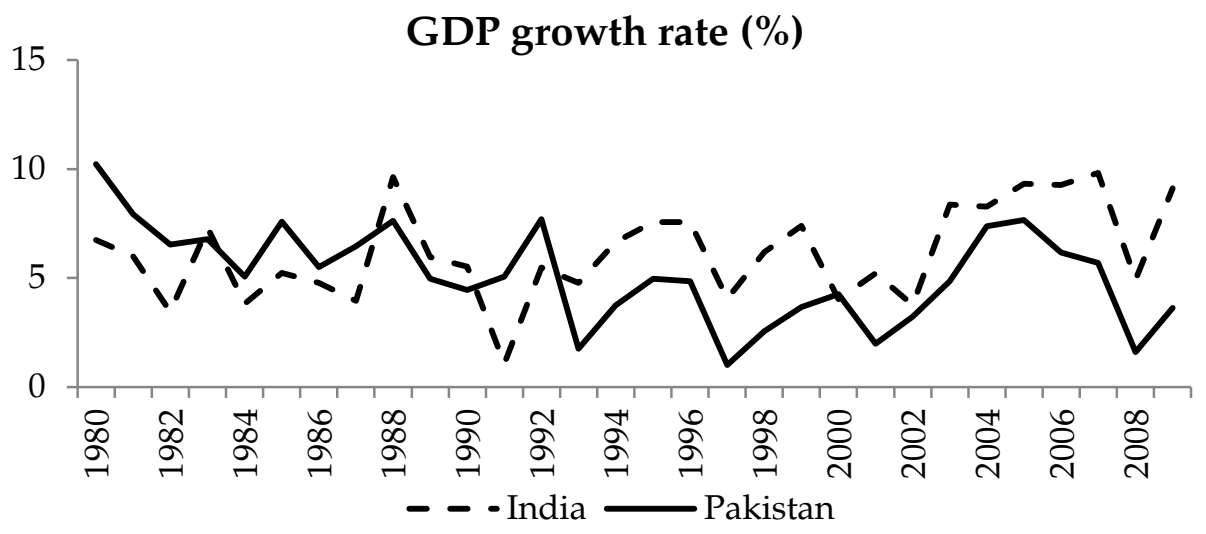

Source: World Bank (2011), World development indicators.

Figure 4: Current and projected GDP per capita in Pakistan and India (in the absence of a pickup in Pakistan's growth)

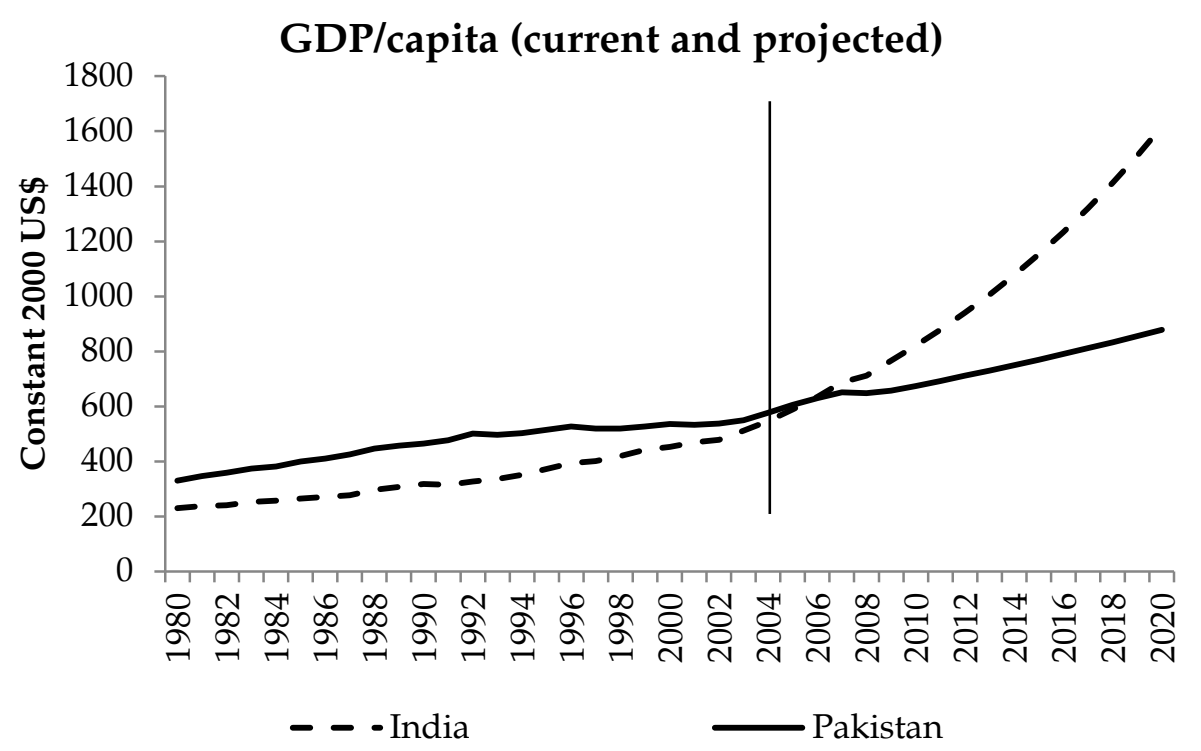

Note: These projections have been done using growth rates averaged over the last 5 years. Source: World Bank (2011), World development indicators. 
Table 1: Sobering trends in GDP growth

\begin{tabular}{lrr}
\hline GDP indicator & $\mathbf{2 0 0 6}$ & $\mathbf{2 0 2 0}$ \\
\hline Pakistan's GDP as a share of India's GDP (\%) & 14 & 9 \\
GDP per capita in Pakistan as a proportion of India's (\%) & 99 & 54 \\
Value of 1 percent GDP spent on public services in India & 7 & 22 \\
(USD billion) & & \\
Value of 1 percent GDP spent on public services in Pakistan & 1 & 2 \\
(USD billion) & & \\
\hline
\end{tabular}

Thus, in its quest for the next growth vent, Pakistan will want to turn India's growing economic capability to its advantage, bridge the income gap, and then overtake India's growth rate, as it did in the 1960s and 1970s. This is not as ambitious as it might seem, given the current performance of the two economies. As Figure 3 shows, in most years in the 1980s, Pakistan's GDP growth was higher than that of India. Furthermore, even now, Pakistan ranks higher than India on many indicators of the cost of doing business (Table 2). Thus, a solid foundation already exists on which to build a mutually beneficial economic relation with India. 


\section{Table 2: Comparison of investment and cost-of-doing-business indicators (2010)}

\begin{tabular}{|c|c|c|}
\hline Indicators & Pakistan & India \\
\hline Trade: Cost to export (USD per container) & 611.0 & $1,055.0$ \\
\hline Trade: Cost to import (USD per container) & 680.0 & $1,025.0$ \\
\hline Trade: Time to import (days) & 18.0 & 20.00 \\
\hline $\begin{array}{l}\text { Ease of doing business index }(1=\text { easiest to } 183=\text { most } \\
\text { difficult })\end{array}$ & 83.0 & 134.0 \\
\hline $\begin{array}{l}\text { Cost of starting a business (percent of income per } \\
\text { capita) }\end{array}$ & 10.7 & 56.5 \\
\hline Time required to start a business (days) & 21.0 & 29.0 \\
\hline Procedures required to start a business (number) & 10.0 & 12.0 \\
\hline Total tax rate (percent of profit) ${ }^{1}$ & 31.6 & 63.3 \\
\hline Profit tax $(\%)^{2}$ & 14.3 & 24.0 \\
\hline Other taxes $(\%)^{3}$ & 2.3 & 21.1 \\
\hline Tax payments (number) $)^{4}$ & 47.0 & 56.0 \\
\hline Time required to enforce a contract (days) & 976.0 & $1,420.0$ \\
\hline Cost of enforcing a contract (percent of claim) & 23.8 & 39.6 \\
\hline Procedures required to build a warehouse (number) & 12.0 & 37.0 \\
\hline Closing a business: Cost (percent of estate) & 4.0 & 9.0 \\
\hline Closing a business: Recovery rate (cents on the dollar) & 36.5 & 16.3 \\
\hline
\end{tabular}

1 The total tax rate (percentage of profit) measures the amount of taxes and mandatory contributions payable by businesses after accounting for allowable deductions and exemptions as a share of commercial profits. Taxes withheld (such as personal income tax) or collected and remitted to tax authorities (such as value added taxes, sales taxes or goods and service taxes) are excluded. http://data.worldbank.org/indicator/IC.TAX.TOTL.CP.ZS 2 Profit tax (percentage of commercial profits) is the amount of tax on profits paid by a business. http://data.worldbank.org/indicator/IC.TAX.PRFT.CP.ZS

${ }^{3}$ Other taxes payable by businesses (percentage of commercial profits) include the amounts paid for property taxes, turnover taxes, and other small taxes such as municipal fees and vehicle and fuel taxes. http://data.worldbank.org/indicator/IC.TAX.OTHR.CP.ZS

4 Tax payments (number) by businesses are the total number of taxes they pay, including electronic filing. The tax is counted as paid once a year even if payments are more frequent. http://data.worldbank.org/indicator/IC.TAX.PAYM

Source: World Bank (2009), Doing business 2010.

\section{Searching for a New Growth Vent}

While a strong internal north-south corridor has helped create a vibrant Indus Basin market, it has also turned Pakistan into a lopsided economy. Thus, despite a relatively small coastline relative to its land borders with three major economies (Iran, China, and India) and one 
important region (Central Asia), the bulk of Pakistan's economic contact with an increasingly globalizing world is through one port city, Karachi, which is a mega-growth node. This strategy worked well for 60 years, but given the congestion of Karachi's ports and the city's complex and volatile politics, it may now have run its course.

This article argues that a new growth vent, one that will yield a prolonged period of growth as the canal colonies did 100 years ago, requires tapping into external lucrative markets in a manner that will create multiple entre-ports for growth (such as Lahore, Peshawar, and other ports on the Sindh/Balochistan coastline). Such a growth vent will enable the country to achieve a sustained growth path that is not as susceptible to the political vicissitudes of one mega-growth node.

\subsection{A Historical Perspective}

Pakistan's border regions have shared systems of economic transactions and cultural ties with neighboring regions that lie outside its current political borders. The area that is now Pakistan was home to one of the world's earliest civilizations. For centuries, this region held a central position in relation to the rest of the world, a place where different societies mingled, culturally and economically. Cities such as Lahore, Multan, and Peshawar, and those in upper Sindh lay on trade routes connecting lands to their west-Iran, Central Asia, and China - and those to the east-India (Figure 5). They became centers of trade, commerce, and culture and brought prosperity to the regions they commanded (Figure 6).

Lahore in Punjab was the center of trade, commerce, finance, and education for a region that included Indian Punjab, Haryana, the Jammu and Kashmir valleys, and Himachal Pradesh to its east, and linked these regions with Persia and Central Asia to its west. However, Lahore was cut off from the lands to its west with the coming of the British and from those to the east soon after 1947 as a result of India-Pakistan feuds.

The ancient walled city of Peshawar has cast a large shadow on South Asian culture. A number of famous Indian actors (the Kapurs, Dilip Kumar, and Shahrukh Khan) hail from Peshawar as do several world squash champions. The city's prominence stems from its history-its merchants constituted a prosperous hub of economic transactions between South Asia and the Central Asian territories. The influence of trade on the surrounding Pashtun areas could also have been substantial had imperial rivalry between Russia and Britain not cut off Peshawar from its northern 
markets and had 1947 not severed access to the Indian market. Subsequently, the pool of economic transactions for Peshawar shrank dramatically. It is also noteworthy that the modern "Silk Route" through Hazara and Gilgit-Baltististan on the Chinese border is an attempt to recreate the ancient trade links that were severed during colonial times.

Sindh has been hugely significant in shaping Pakistan's religious/cultural psyche, which is historically embedded in the venerated Sufi tradition of Islam. The Sufi saints chose to settle in Sindh along the Indus because there were receptive host communities that benefited from the trade routes between markets in territories that now lie in India and Iran through Balochistan.

Figure 5: The cultural influences that have shaped Pakistan

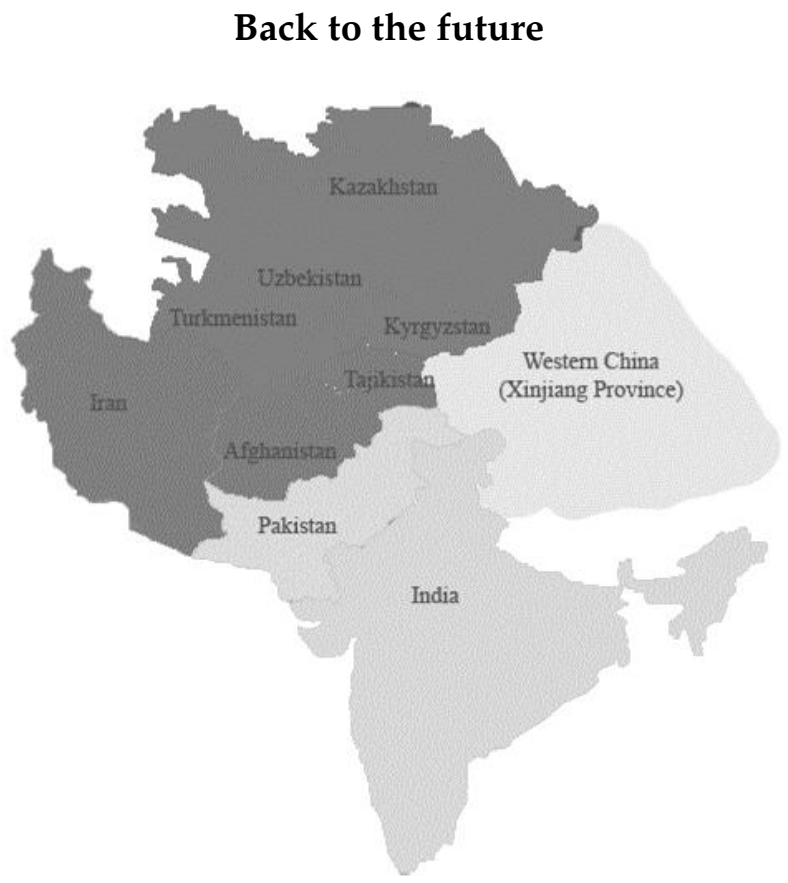


Figure 6: .... and the east-west trade routes they spawned

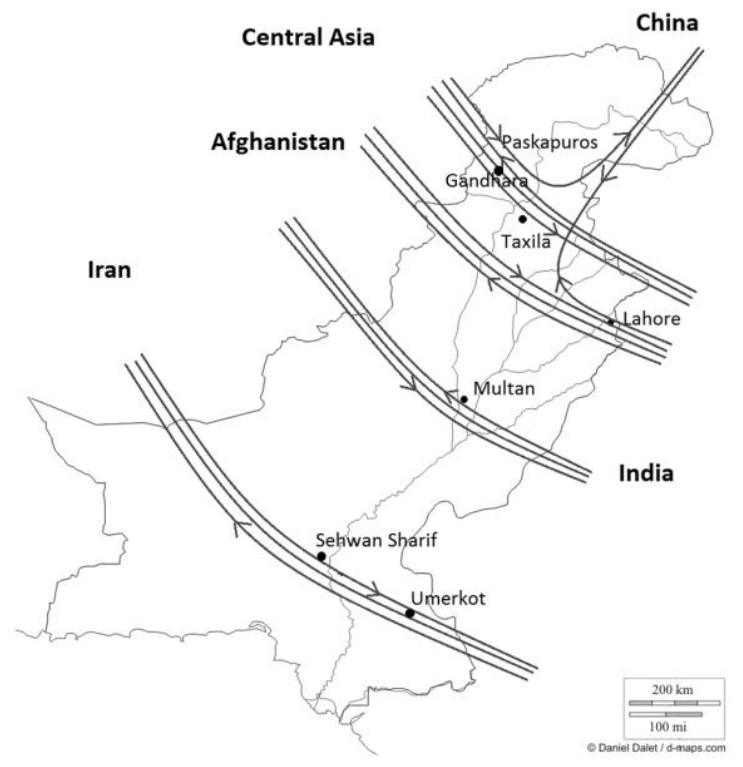

Historically, these cultural centers have defined themselves as parts of much larger regions that lie outside the borders of the modern nationstate of Pakistan. Indeed, they were better connected with trade and cultural centers outside modern Pakistan than those that lie within it. This has posed a challenge for the country's nation builders. Hemmed in by colonial borders on one hand and bad relations with India on the other, Pakistan's policymakers have attempted to reshape the country's economic geography. Departing from historical patterns that emerged over centuries, they created the north-south corridor defined by new borders, which, as discussed earlier, facilitated the major growth vents of the last six decades.

\subsection{The Changing World Around Pakistan's Land Borders}

As recently as the 1980s, it did not matter that the old east-west trade routes lay abandoned. China was in a long slumber and performing far below its capabilities as a potential economic giant. Western China, in particular, was mired in low growth and, for Pakistan, that was the more relevant region. Central Asia's mineral wealth was being exploited in Russian interests. India, with its low "Hindu" growth rate, was shackled to a heavy-handed and stifling regulatory framework born of Fabian aspirations and a decaying colonial bureaucratic heritage. In the last 30 years, however, all this has changed. 
Under Deng Xiao Peng, China arose from its slumber in the early 1980s and has since become an economic powerhouse with growth rates of 10 percent per annum for over two decades. It is undergoing major restructuring to deepen growth beyond the Pacific coast to western China, which will bring it to Pakistan's northern land border. The rising Chinese middle class constitutes a huge consumer market for Pakistani products. China's high savings could be a deep pool of investment for Pakistan. An economy of over a billion people with the potential to grow at 10 percent for several more decades beckons from across Pakistan's northern border.

India followed China a decade later, with the reforms of Prime Minister Narasimha Rao. Its cumbersome regulatory framework is being dismantled and its spectacular growth in the information technology sector has given India a "techie" shine that has attracted world attention. The country is on an impressive growth trajectory of 7-8 percent growth per annum and is now recognized as a major emerging economic power. In short, another economy of over a billion people, high savings, and rising living standards lies beyond Pakistan's long eastern land border.

Across the northwestern border, beyond troubled Afghanistan and our own volatile tribal belt, are the newly independent Central Asian republics-Turkmenistan, Uzbekistan, Kazakhstan, Kyrgyzstan, and Tajikistan. Rich in natural resources that are no longer being siphoned off by the Soviet behemoth, the Central Asian republics are engaging with the world to exchange their mineral wealth for goods and services that satisfy the growing consumption and rising living standards of their citizens. Finally, beyond Pakistan's western border lies Iran, rich in oil and natural gas that it would be free to sell to needy South Asia in exchange for skilled labor and consumption goods once its strategic interests are allied with its citizens' welfare.

The figures below show the changing economic profiles of the countries discussed above in terms of growth in size of GDP (Figure 7); population (Figure 8); size of crude oil, gas, and currency reserves (Figures 9-11) and the rapid increase in imports by energy-rich Central Asia (Figure 12 and Table 3). The last two are striking in that they reveal how little of the increase in Central Asian imports comes from South Asia. In turn, this underscores the absence of the traditional east-west trade corridor that could have enabled South Asia to take a much larger share of Central Asian imports compared to the current situation. 
Figure 7: Rapidly growing economies across Pakistan's land borders

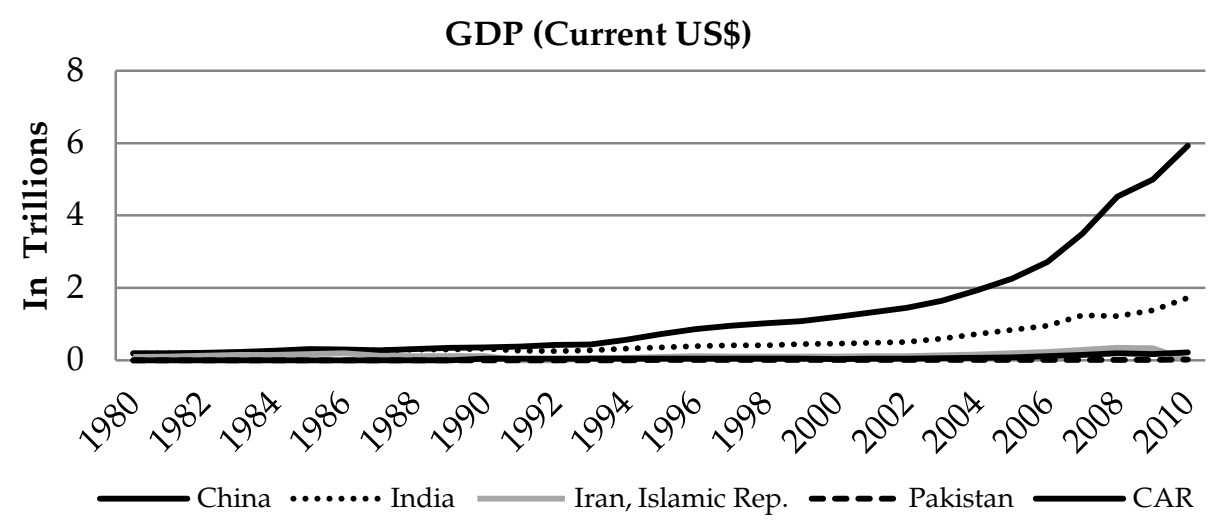

Figure 8: Potential for further growth measured by population

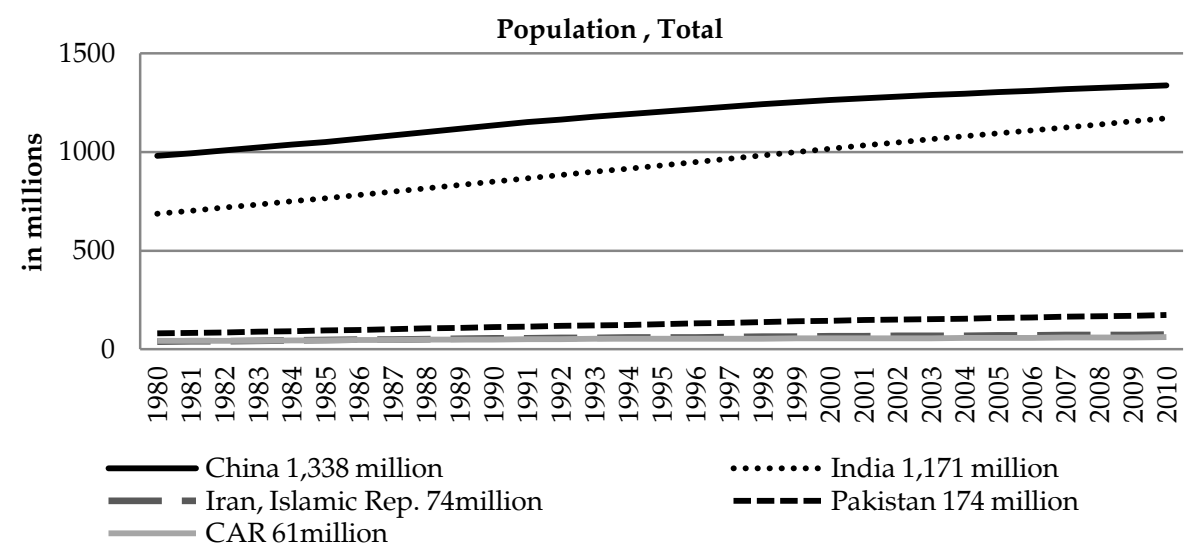

Figure 9: Crude oil reserves in countries across Pakistan's land borders

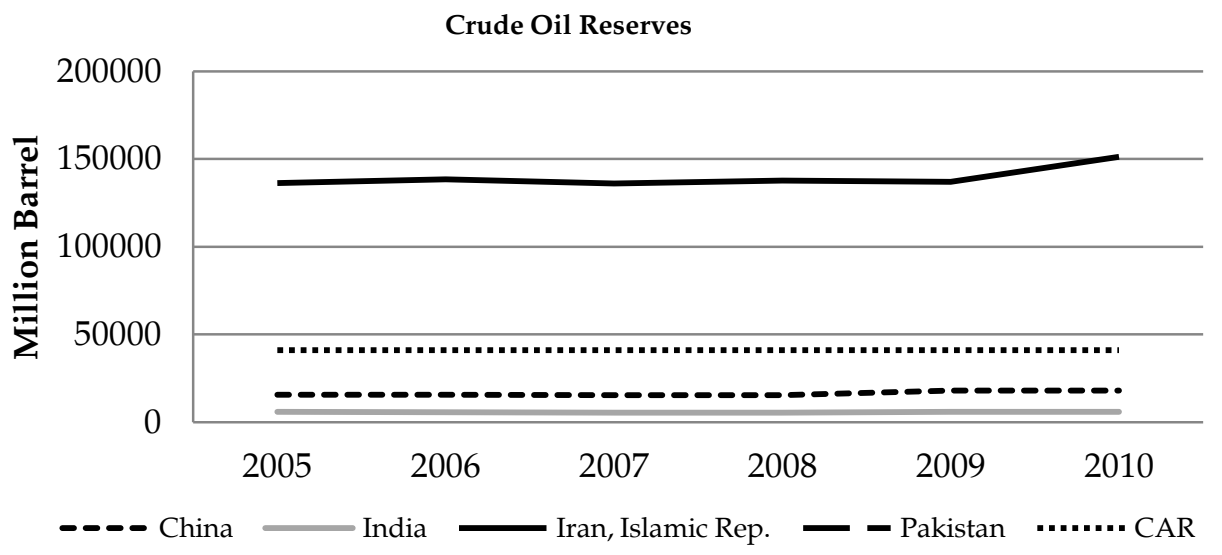


Figure 10: Gas reserves in countries across Pakistan's land borders

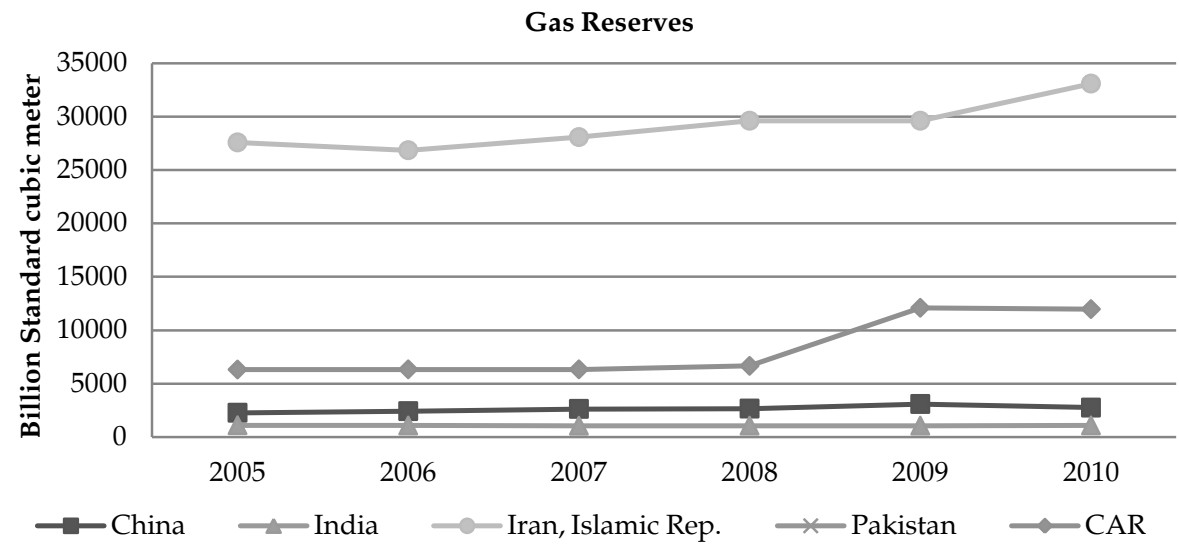

Figure 11: International reserves accumulation in countries across Pakistan's land borders

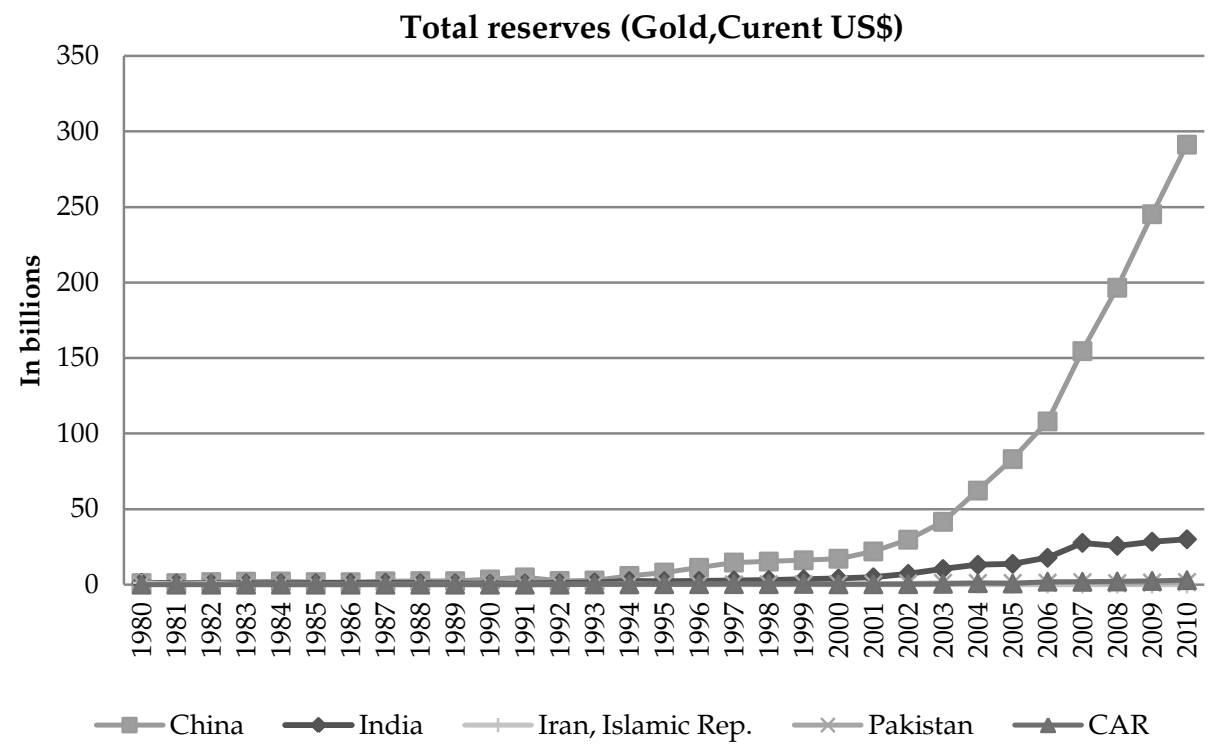


Figure 12: Increase in imports of Central Asian republics

UZBEKISTAN

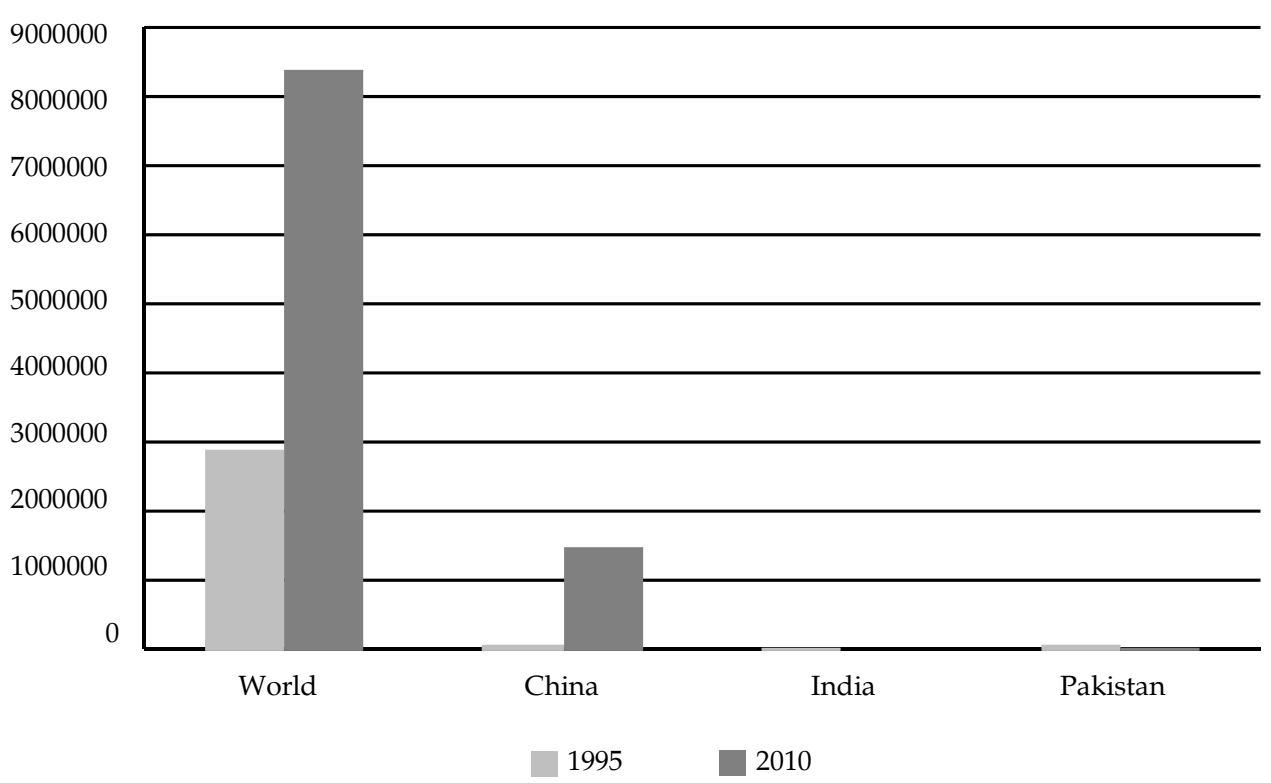

Table 3: Regional sources of Central Asian imports

\begin{tabular}{|c|c|c|c|}
\hline Country & $\begin{array}{l}\text { Imports, } 2008 \\
\text { (USD billion) }\end{array}$ & Major imports & $\begin{array}{l}\text { Import trading } \\
\text { partners }\end{array}$ \\
\hline Kazakhstan & 37.530 & $\begin{array}{l}\text { Machinery and equipment, } \\
\text { metal products, foodstuffs }\end{array}$ & $\begin{array}{l}\text { Russia, China, } \\
\text { Germany }\end{array}$ \\
\hline Kyrgyzstan & 3.476 & $\begin{array}{l}\text { Mineral products, } \\
\text { machinery and electrical } \\
\text { equipment, chemical } \\
\text { products, foods and } \\
\text { beverages, textiles }\end{array}$ & $\begin{array}{l}\text { China, Russia, } \\
\text { Kazakhstan }\end{array}$ \\
\hline Tajikistan & 3.200 & $\begin{array}{l}\text { Fuels, electric power, } \\
\text { aluminum oxide }\end{array}$ & $\begin{array}{l}\text { Russia, Kazakhstan, } \\
\text { Uzbekistan, China }\end{array}$ \\
\hline $\begin{array}{l}\text { Turkmenista } \\
\mathrm{n}\end{array}$ & 5.291 & $\begin{array}{l}\text { Machinery and transport } \\
\text { equipment, chemicals, foods }\end{array}$ & $\begin{array}{l}\text { United Arab } \\
\text { Emirates, Azerbaijan, } \\
\text { US }\end{array}$ \\
\hline Uzbekistan & 6.500 & $\begin{array}{l}\text { Machinery, chemicals, } \\
\text { plastics, foods, and metals }\end{array}$ & $\begin{array}{l}\text { Russia, Rep. of Korea, } \\
\text { Germany, China }\end{array}$ \\
\hline
\end{tabular}

Sources: Federal Research Division, Library of Congress (http://memory.loc.gov/frd/cs/profiles/); Central Intelligence Agency (https://www.cia.gov/library/publications/the-world-factbook/); United Nations (http://data.un.org/). 


\section{What Pakistan Needs}

The east-west economic routes-which go beyond trade in goods and include energy flows, the movement of workers, and investment flows-and the growth vent associated with them will not be realized till there is peace in Afghanistan, Pakistan's tribal belt straddling the Afghan border is stabilized, and Balochistan effectively re-engages with the federation. Furthermore, without normalizing trade with India, the Indus Basin will remain a T-junction rather than a crossroads of economic transactions, which will limit the welfare gains from the new growth vent.

\subsection{Stabilizing the Durand Line}

To contribute to peace in Afghanistan, the concept of strategic depth needs to be revisited and cast in terms of deepening economic transactions. Residents on both sides of the Durand Line well understand the welfare gains to be garnered via economic synergies between Peshawar and Jalalabad on one hand and Kandahar and Quetta on the other. Pakistan's light engineering sector can service the rich agricultural lands in Afghanistan and, in turn, become a market for Afghanistan's cash crops, demand for which could extend to all of South Asia. Pakistan's financial sector and flourishing private school networks could provide key services and assist Afghanistan in building its own systems. The extension of roads beyond the Durand Line and trade-facilitating infrastructure on the border would be a precursor to trade in Afghanistan's substantial mineral wealth.

Throughout history, Pakistan's land-poor tribal belt has looked to out-migration for sustenance. Canal irrigation in the Peshawar valley and the plains of Mardan was a major growth vent in the past. Many tribespeople settled on the lands and brought about lasting productivity, improvement, and prosperity. During Pakistan's import-substituting industrialization phase, Karachi became a magnet for jobs and entrepreneurial activity, attracting a large number of tribespeople. As a result, it is today the largest Pathan-populated city where people with strong connections with the tribal belt dominate the transport sector and its networks throughout the Indus Basin market.

As trend economic growth declined in Pakistan and job creation slowed down, people from the tribal belt found opportunities abroad, especially in Saudi Arabia and the oil-rich Gulf states. With the decline in economic dependence on Pakistan, the tribal belt's relationship with the federation weakened, contributing to the ongoing militancy. The relationship of mutual dependence between the federation and tribal belt 
needs to be restored. This will require higher economic growth in Pakistan, ensuring that the tribal belt benefits from regional trade via the transport networks, and upgrading skills in the area to allow its citizens to secure higher-wage employment in the Middle East.

\subsection{The Centrality of Balochistan}

Balochistan will be central to Pakistan's prospect of becoming a regional hub for trade in goods and energy. The province's strategic location makes it pivotal both for the east-west and north-south trade routes. The historical trade route linking markets in Indian Gujrat, upper Sindh, and Iran traverses Balochistan, as does the trade route to Kandahar in Afghanistan and beyond to Central Asia. Thus, establishing peace in Balochistan and upgrading its infrastructure and transport networks along the east-west routes must become a priority both for the province's development as well as for Pakistan's own overall economic growth.

Balochistan also offers exciting prospects with considerable economic benefits in terms of a second north-south trade corridor. These arise from the province's 800-kilometer-long Makran coastline on the Arabian Sea and Indian Ocean. According to some estimates,

90 percent of inter-continental trade and two thirds of all petroleum supplies travel by sea. Globalization relies ultimately on shipping containers, and the India Ocean accounts for one half of all the world's container traffic. Moreover, the Indian Ocean rim land from the Middle East to the Pacific accounts for 70 percent of the traffic of petroleum products for the entire world. Indian Ocean tanker routes between the Persian Gulf and South and East Asia are becoming clogged, as hundreds of millions of Indians and Chinese join the global middle class, necessitating vast consumption of oil (Kaplan, 2011).

Kaplan goes on to write, "If there are great place names of the past-Carthage, Thebes, Troy, Samarkand, Angkor Wat-and of the present Dubai, Singapore, Tehran, Beijing, Washington-then Gwadar might qualify as a great place name of the future." 
Raman (2009) muses:

So imagine now a bustling deepwater port with refuelling and docking facilities at the extreme Southwestern tip of Pakistan, more a part of the Middle East than of the Indian Sub-continent, equipped with highway and oil and natural gas pipelines that extend northeast all the way through Pakistan ---cutting through some of the highest mountains in the world, the Karakorams---into China itself, from where more roads and pipelines connect the flow of consumer goods and hydrocarbons to China's middle class fleshpots farther east.

Wirsing (2008) points out that "the pipelines would also be used to develop China's restive, Muslim far west; indeed, Gwadar looked poised to cement Pakistani and Chinese strategic interests."

Meanwhile, another branch of this road and pipeline network would go from Gwadar north through a future stabilized Afghanistan, and onto Iran and Central Asia. In fact, Gwadar's pipeline network would lead into a network extending from the Pacific Ocean westward to the Caspian Sea. In this way, Gwadar becomes a pulsing hub of a new silk route, both land and maritime: a mega project and gateway to landlocked, hydrocarbon-rich Central Asia-an exotic twenty-first century place name.

Thus, both Islamabad and Quetta have much to gain from a joint strategy of economic growth based on regional trade. This requires strengthening the relationship of mutual dependence and trust. To that end, the $18^{\text {th }}$ Amendment to the Constitution and the supporting $7^{\text {th }}$ National Finance Commission (NFC) Award in 2010 was an important first step. The constitutional amendment virtually eliminates the concurrent list and transfers most of the responsibility for economic development to the provinces. To back this up financially, the NFC award has reduced the federal share of the pool of resources and substantially increased Balochistan's share. This follows from greater weight given to underdevelopment and thin population density (which increases the cost of service delivery) in the distribution formula. In turn, Balochistan needs to develop its capacity to utilize the additional resources more effectively. The NFC award presents opportunities to that end. National investment priorities to promote regional trade could be dovetailed with complementary Balochistan investments via the provincial annual 
development plan to implement a comprehensive strategy for upgrading infrastructure that supports larger volumes of regional trade.

The federation also needs to revisit the sensitive issue of natural resource pricing, given the perception that it is skimming off large rents. Natural gas is a case in point. Subsidizing natural gas for urban residential consumers, most of them in Punjab and Karachi, by keeping well-head prices far below international prices fuels resentment in Balochistan.

The land grab in Gwadar has not helped in building trust between the Baloch and the federation. As Gwadar's prospects brightened with the construction of the port, the rich and well-connected from Karachi, Lahore, and other parts of Pakistan are alleged to have bribed low-ranking local officials to allot them land at rock-bottom prices, which they then sold off to developers at much higher prices, thus skimming off huge speculative rents. The Baloch regard this as theft and cite it as an example of the unfair treatment meted out to them by the federation. Solutions such as a turnover tax on each land transaction that is deposited in a fund for the exclusive use of the Baloch in Gwadar would help allay such perceptions.

These examples show that Pakistan must explicitly incorporate regional equity into its national development strategy. The fact that Balochistan has less than 5 percent of the country's total population of 180 million but most of its mineral wealth and coastline should be enough incentive to pursue such strategies.

\subsection{Engaging with India}

A number of studies (Khan, 2009; Nabi, 2012; Nabi \& Nasim, 2001; Naqvi \& Nabi, 2008) have estimated the salutary impact of India-Pakistan trade liberalization on Pakistan's economy, both in terms of overall trade volumes as well as on the vast majority of stakeholders. Pakistan's role as a hub of regional trade is incomplete unless the east-west-and northsouth—-trade routes extend to India.

Figure 13 illustrates trade flows that indicate the greater vibrancy of Indus Basin economic transactions, following the re-establishment of the east-west trade corridors. Liberalizing the country's economic relationship with India takes on greater urgency if Pakistan is to enjoy the current entrypoint comparative advantage in the cost of doing business, and especially the advantage in infrastructure efficiency. This advantage will be eroded as India reduces business costs and improves its infrastructure. Had Pakistan 
liberalized 20 years ago, it would have enjoyed the entry-point advantage of a far better overall investment climate that has eroded over time.

India's recent (1st August 2012) liberalization of its investment regime-lifting the ban on foreign direct investment from Pakistan into India-and Pakistan's earlier announcement that it would move from positive list-based to negative list-based bilateral trade (granting India most favored nation [MFN] status) are welcome developments. However, for trade to resume on a meaningful scale, several remaining stumbling blocks need to be addressed.

The granting of MFN status to India was accompanied by the announcement of a long and unwieldy negative list of 1,200 items. Pakistan has stated that the list will be phased out in a year, and it must adhere to this timetable. In addition, a bilateral commission should be set up to address the issues that are closely tied to India and Pakistan having a normal economic relationship with sustained benefits. The commission should focus on the following areas.

1. Goods- and services-related nontariff barriers (NTBs): The objective would be to use the WTO framework to address Indian (and Pakistani) NTBs and then bring these into the strategic regional trade policy framework outlined above. The institutional capacity (National Tariff Commission) to address NTBs and antidumping complaints should be developed with a view to promoting rather than hindering trade.

2. Land routes: The maximum benefits of a more liberal trade regime with India will come from land routes that minimize response time to market forces. This will require opening up as many overland routes as possible, building on the old road and railway networks all along the border from the Kashmir region to the Arabian Sea.

3. Travel: Travel (visas, air/road/railway transport) must be facilitated to promote competitive trade in goods and services that will benefit small and medium-sized firms. This will make it possible to tap into the large pool of Indian skilled workers, gain access to Indian farm and other technology, and encourage cross-border tourism. 
Figure 13: Enhancing the vibrancy of north-south (Indus Basin) trade flows by reopening the historical east-west trade routes

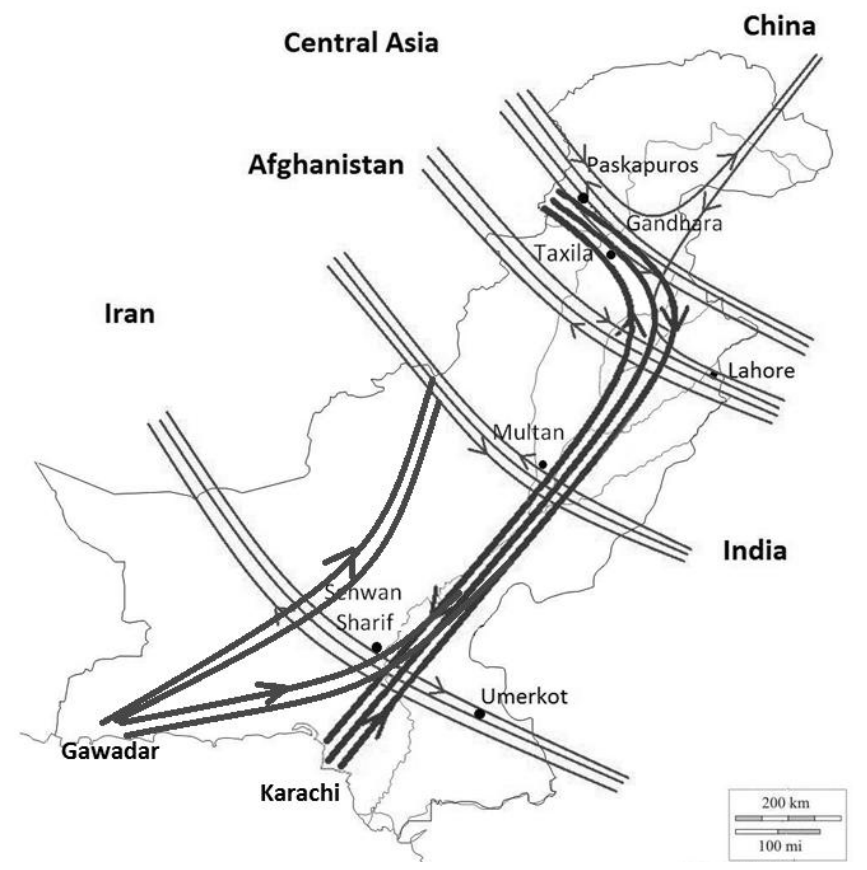

To create a sustained momentum for liberalizing trade and investment flows, it would be useful to set up a regional trade forum comprising the private sector, academia, and the media, to monitor the working of the bilateral commission described above. The forum should (i) identify barriers to trade embedded in the trade policy, payment system, and communications (including travel); (ii) help identify the losers from the trade liberalization process and suggest ways of compensating them; and (iii) help formulate a broader regional trade and investment promotion strategy.

\subsection{India's Role in Promoting Bilateral and Regional Trade ${ }^{1}$}

All paths to economic development and prosperity do not have to be routed through sweatshops catering to affluent western consumers. A large and vibrant Asian regional market would constitute a significant and, given demographic shifts, growing part of global demand for products. India's long-term strategic interest is to help create that Asian market. That, in turn, requires strengthening Pakistan as an effective regional hub that would connect the Asia-wide market.

\footnotetext{
${ }^{1}$ This discussion is based on Nabi (2012, March 28).
} 
Successfully managing the new liberalized India-Pakistan trade regime to scale it up to a full-fledged economic relationship will be vital. In the short term, this may well mean exercising voluntary restraint on exports that might hurt small and medium-sized Pakistani manufacturers. It will also require focusing on the export of machinery and technology to Pakistani firms that currently import these at a high cost from more expensive developed country sources. Joint ventures and other investment strategies will need to be developed to set up production units for the Asiawide market. The visa regime will need to be liberalized and travel facilitated so that small entrepreneurs develop cross-border business linkages and the gains from liberalization can be more widely shared.

\section{Concluding Remarks}

Pakistan's recent growth performance is worrisome because it is far below the trend growth rate and, given its population growth, threatens the objective of sustained welfare improvement for the country's citizens. Furthermore, this poor growth performance is in stark contrast to rising prosperity within the region. China, India, the Central Asian republics, and Iran are all doing well. A review of the major growth vents of the last 60 years shows the important role of policy in promoting economic growth. Policy, furthermore, helped create a strong and well-integrated Indus Basin market, perhaps for the first time in history, through investment in communications and a regulatory framework that allowed the market to promote a network of integrating transactions throughout the Indus Basin. The fact that countries outside the region were caught up in internal turmoil and poor economic governance also helped strengthen this market because Karachi became the principal trading hub for all regions of the country.

The present regional outlook is different. While Pakistan's growth vents have run their course, China and India, both billion-people-plus economies, are the world's new growth engines; the Central Asian republics are ready to exploit their mineral wealth for the welfare of their own citizens, and so will Iran as it begins to engage with the world.

These fast improving regional prospects underscore the importance of Pakistan's centrality as a connector of regional markets. We have shown that this is a familiar role. Historically, three regions in Pakistan-the Peshawar valley and Hazara in the north, Lahore and Multan in the center, and upper Sindh in the south-were on the east-west trade routes that connected markets in the east (now India) with markets in the west (now the Central Asian republics and Iran). As regional trading hubs, they 
enjoyed cultural richness and economic prosperity and were hugely influential in shaping the South Asian identity.

This article argues, furthermore, that reopening the historical eastwest trade routes to trade in goods and energy will give renewed strength to the Indus Basin market by increasing the flow of economic transactions. It will also help restore the economic and cultural vibrancy of the subregions and promote more equitable growth. The new growth vent, one that will give sustained high growth for several decades, thus entails Pakistan reoccupying its centrality as a hub for regional trade.

Becoming a regional hub entails normalizing economic relations with India. The transactions dynamics of a $\mathrm{T}$-junction, i.e., regional trade without India, are different from those of a hub, i.e., regional trade with India included. A good beginning has been made with the resolution of India's MFN status and the liberalization of the bilateral investment regime. This should be followed up by paring down the negative list, addressing NTBs, allowing multiple trade points along the border, and most importantly, facilitating travel for business and tourism. A liberal visa regime will make small businesses stakeholders in regional trade, which is essential to keep the process on track, given the political pitfalls in IndiaPakistan relations.

Sustained welfare improvements for the citizens of a regional hub arise when it transitions from being a transportation hub for goods and energy into a manufacturing hub that creates high-productivity, high-wage jobs in multiple regional growth nodes. Such a transition requires strengthening Pakistan's international competitiveness as a manufacturing base. Key to this is a skilled workforce, modern infrastructure (ports, roads, and energy), substantially improved governance to improve service delivery, and a development framework that promotes investment and manufacturing over consumption. Several recent studies detail ongoing/proposed reforms in each of these areas. ${ }^{2}$ These need to be distilled to draw up an agenda of reform for the medium term aimed at strengthening Pakistan's international competitiveness. This will help make the transition from a transportation hub to a manufacturing hub that can sustain high growth and create employment opportunities that improve living standards across Pakistan.

\footnotetext{
2 See Pakistan, Planning Commission (2011); Nabi (2010); Education and Skills, Governance Reform, National Transport Corridor, Fiscal Reform, Industrialization, Provincial Economic Reports and Clusters by World Bank.
} 


\section{References}

Caroe, O. (1958). The Pathans. Karachi, Pakistan: Oxford University Press.

Hamid, N., \& Tims, W. (1990). Agricultural growth and economic development: The case of Pakistan (Working Paper No. 13). Paris, France: Organisation for Economic Co-operation and Development.

Hasan, P. (1998). Pakistan's economy at the crossroads: Past policies and present imperatives. Karachi, Pakistan: Oxford University Press.

Kaplan, R. D. (2011). Monsoon: The Indian Ocean and the future of American power. New York, NY: Random House.

Khan, M. S. (2009). India-Pakistan trade: A roadmap for enhancing economic relations (Policy Brief No. PB09-15). Washington, DC: Peterson Institute for International Economics.

Lewis, S. (1969). Economic policy and industrial growth in Pakistan. London, UK: George Allen and Unwin.

Mullick, H. (2004, June). US foreign aid and economic growth: A post-9/11 case study of Pakistan as a key ally in the war against terrorism. In Proceedings of the Pennsylvania Economic Association Conference 2004.

Nabi, I. (2010). Economic growth and structural change in South Asia: Miracle or mirage? (Monograph). Lahore, Pakistan: Lahore University of Management Sciences, Development Policy Research Center.

Nabi, I. (2012, March 28). Lifting up the India-Pakistan trade game. The Hindu.

Nabi, I. (2012). Pakistan-India trade: Preparing for a better future. Washington, DC: Woodrow Wilson Center.

Nabi, I., \& Nasim, A. (2001). Trading with the enemy: A case for liberalizing Pakistan-India trade. In S. Lahiri (Ed.), Regionalism and globalization: Theory and practice (pp. 170-197). London, UK: Routledge.

Naqvi, Z., \& Nabi, I. (2008). Pakistan-India trade: The way forward. In M. Kugelman \& R. M. Hathaway (Eds.), Hard sell: Attaining Pakistan's competitiveness in global trade. Washington, DC: Woodrow Wilson Center. 
Pakistan Business Council. (2011). Regional trade panel report. Karachi, Pakistan: Author.

Pakistan, Ministry of Commerce. (1996). Pakistan-India trade: Transition to the GATT regime. Islamabad, Pakistan: Author.

Pakistan, Planning Commission. (2011). Pakistan: Framework for economic growth. Islamabad, Pakistan: Author. Retrieved from http://www.pc.gov.pk/hot links/growth_document_english_version.pdf

Raman, B. (2009). Hambantota and Gwadar: An update. Chennai, India: Institute of Topical Studies.

Stone, I. (1984). Canal irrigation in British India: Perspectives on technological change in a peasant economy. Cambridge, UK: Cambridge University Press.

Wirsing, R. G. (2008). Baloch nationalism and the geopolitics of energy resources: The changing context of separatism in Pakistan. Carlisle, PA: US Army War College, Strategic Studies Institute.

World Bank. (2006). Pakistan: Growth and export competitiveness. Washington, DC: Author.

World Bank. (2009). Doing business 2010. Washington, DC: Author.

World Bank. (2011). Doing business 2012: Doing business in a more transparent world. Washington, DC: Author.

World Bank. (2010-2011). World development indicators. Retrieved from http://data.worldbank.org/data-catalog/world-development-indicators

Zaidi, S. A. (2005). Issues in Pakistan's economy. Karachi, Pakistan: Oxford University Press. 